\title{
SOBRE O NARCISISMO DISCURSIVO: “EU, PARA MIM”
}

\author{
The Discursive Narcissism: "Me to Myself" Sobre el narcisismo discursivo: "Yo, para mi"
}

\author{
João Carlos Cattelan* \\ Universidade Estadual do Oeste do Paraná, Cascavel, PR, Brasil
}

\begin{abstract}
Resumo: Este trabalho tem o objetivo de dar sustentação à hipótese de que o discurso, às vezes, é comandado por um funcionamento narcisista, simulando-se cordial e flexível (nem sempre), quando, em última instância, apenas almeja (e luta de forma contundente) manter-se numa mirada pessoal e evitar a polêmica e a revisão. O corpus de dados é constituído por memes retirados de postagens no facebook. Valese, como amparo teórico para a constituição do estudo, de postulados da Análise de Discurso de linha francesa, de alguns pleitos da pragmática linguística e, sobretudo, da teorização de Freud sobre o desejo narcísico do indivíduo de transformar o mundo no espelho em que se contempla.
\end{abstract}

Palavras-chave: Discurso. Facebook. Memes. Narcisismo. Eu para Mim.

\begin{abstract}
In this paper, the objective is to sustain the hypothesis where the discourse is sometimes guided by a narcissistic functioning. It would simulate cordiality and flexibility, though not always, when, ultimately, it only aspires, strives hard to maintain itself in a personal mirroring to avoid controversy and revision. The corpus consists of some memes taken from Facebook posts. For this study, as a theoretical basis, we use assumptions of the French Discourse Analysis, some discussions mobilized in the Linguistic Pragmatics and, especially, Freud's theorization on the narcissistic desire of the individual in transforming the world into a mirror for self-reflection.
\end{abstract}

Keywords: Discourse. Facebook. Memes. Narcissism. Me to Myself.

Resumen: Este trabajo tiene el objetivo de ofrecer sustentación a la hipótesis de que el discurso, a veces, está ordenado por un hilo de funcionamiento narcisista, simulándose le cordial y flexible (ni siempre), cuando, en última instancia, solo anhela (y lucha de modo contundente) mantenerse en una mirada personal y evitar la polémica y la revisión. El corpus de datos está constituido por memes sacados de publicaciones en Facebook. Para la constitución del estudio, son utilizadas la perspectiva teórica del Análisis de Discurso de línea francesa, algunas cuestiones de la pragmática lingüística, y sobre todo la teorización de Freud acerca del deseo narcisista del individuo de transformar el mundo en el espejo en el que se contempla.

Palabras clave: Discurso. Facebook. Memes. Narcisismo. Yo para Mí.

* Professor doutor. Docente no curso de Pós-Graduação em Linguagem e Sociedade (Mestrado e Doutorado), Cascavel, Estado do Paraná. ORCID: https://orcid.org/0000-0002-7838-5284. E-mail: jcc.cattelan@gmail.com. 
"O amor é o nosso

Verdadeiro destino

Não descobrimos

o verdadeiro sentido

da vida sozinhos,

achamos com o outro".

(Thomas Merton)

\section{INTRODUÇÃO}

Em que pese o estranhamento que possa provocar, começo pela retomada do mandamento cristão, não pelo valor intrinsecamente religioso (apesar de não poder ser negado, sob a condição de a fé se transformar em prática), mas pelo discernimento em relação à psicologia humana mais profunda: trata-se do princípio de "amar ao próximo como a si mesmo", ditame exigente em face do narcisismo humano, mais propenso à autossatisfação individual do que ao atendimento do bem-estar do outro. Há no preceito uma percepção do hedonismo humano, que se faz à revelia dos afetos do outro.

Pedir que se ame ao outro como a si próprio atenta para o individualismo humano e para a pulsão que leva ao desequilíbrio entre o bem próprio e o do próximo. Ao lado de uma compreensão profunda da natureza egoica humana, ou por causa dela, o mandamento exige que o que não se quer para si não se queira para o outro e que o que se quer para si se queira para o outro. $\mathrm{O}$ atendimento deste primado determina, no limite, a renúncia a certas fontes de prazer: inclusive, a que leva a sentir prazer com a dor do outro ou, neste estudo, a fazer do discurso uma camisa de força incapaz de retificação, ainda que o seja por meio da criação de um efeito de liberalidade.

Educado no contexto de uma ética religiosa que exige empatia, com a abnegação e o altruísmo que impõe, chamou-me a atenção, quando precisei de acompanhamento psicológico para superar um evento dramático, a insistência da psicóloga em que eu devia pensar em mim, em que pesasse haver diversas pessoas no episódio. Tudo se passava como se os afetos e as paixões dos outros devessem ser subsumidos pelos meus.

Dado o confronto interdiscursivo ${ }^{1}$ que, às vezes, era explícito, começava a tomar forma a suspeita de que a ética que me constituía era rejeitada em face da relação polêmica tecida sob o primado de amar a mim mesmo à revelia do outro. Contrariamente à ética $\mathrm{e}$ à moral do preceito cristão, eu era posto na condição de, em linhas gerais, elaborar o "luto" para que o prazer pudesse vigorar. Não estou afirmando que deveria ser de outra forma, mas apenas atento para um certo funcionamento discursivo.

\footnotetext{
${ }^{1}$ Dito de forma sumária, o interdiscurso diz respeito à tessitura que se tece entre discursos distintos, se bem que não sempre, em geral, por meio do embate polêmico de dois pontos de vista ou miradas valorativas distintas (Ver: Pêcheux (1995) e Maingueneau (2005)). Para Pêcheux (1995, p. 162), o interdiscurso possui uma "objetividade material contraditória [...] que reside no fato de que 'algo fala' 'antes, em outro lugar e independentemente" retomado pelo discurso atual, com o que coaduna a tese de Maingueneau (2005) de que, na gênese dos discursos, há em embate entre duas formações discursivas num espaço discursivo
} 
Os eventos me fizeram ver que, no discurso ${ }^{2}$ da psicóloga, outros de teor idêntico circulam em diferentes espaços, colocando a perspectiva individual como fator crucial de definição. Um consolidou a minha percepção: posts $^{3}$ de usuários de facebook. A toada da manutenção de um ponto de vista à revelia de qualquer celeuma se revelou o princípio de funcionamento de um discurso em que, sob a aparência de liberalidade e respeito à visada antagônica, há uma rejeição apriorística de qualquer debater retificador: ou um narcisismo de caráter discursivo ${ }^{4}$. Tenho como objetivo dar sustentação a esta hipótese.

\section{PREPARANDO O TERRENO - MEME 1}

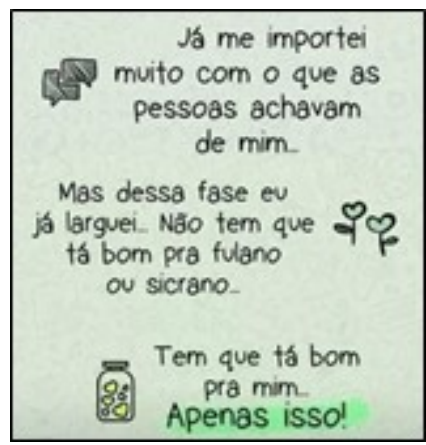

\section{Figura 1 - Meme 1}

Fonte: https://pics.me.me/ja-me-importei-muito-com-o-que-as-pessoas-achavam-10608247.png

O primeiro meme de que me valho é constituído por três enunciados ${ }^{5}$ verbais; atento para a forma com que cada um é produzido, para tornar precisa a tese que defendo. Do mesmo modo que este é o dado inicial, poderia ser o último, uma vez que é canônico em relação ao narcisismo discursivo de autocentramento. Trazê-lo à frente traz a vantagem de delimitar o caminho que busco trilhar para alcançar o objetivo estabelecido.

2 Utilizo o conceito de discurso neste trabalho de acordo com a definição dada por Pêcheux na AAD-69. Para ele, "Chamaremos discurso uma sequência linguística de dimensão variável, geralmente superior à frase, referida às condições que determinam a produção dessa sequência em relação a outros discursos, sendo essas condições propriedades ligadas ao lugar daquele que fala e àquele que o discurso visa, isto é, àquele a quem se dirige formal ou informalmente, e ao que é visado através do discurso" (p. 214).

3 Os dados de que me valho para o estudo têm sido designados como "memes", referindo-se a um gênero discursivo que circula na internet, que conjuga texto verbal e não-verbal, em que o plano verbal é composto por enunciados curtos, em que a imagem possui poucos ingredientes e que, sobretudo, tem um fundamento irônico, satírico ou polêmico em torno de algo que está sendo comentado no momento. Conforme o Wikipédia, "Na internet, a expressão 'meme' é usada para se referir a qualquer informação que viralize, sendo copiada ou imitada na rede. Geralmente esses memes são imagens, vídeos ou gifs de conteúdo engraçado, e que acabam se espalhando na internet por meio das redes sociais ou fóruns".

4 Alerto que uso 'narcisismo' neste estudo não como o compreende a psicanálise, mas de uma forma um tanto deslocada, cujo intuito é o de recobrir um funcionamento discursivo que se simula liberal, para não se submeter a alguma revisão que viria de um confronto polêmico. 'Narcisismo', neste sentido, significa a recusa de se mirar em outro espelho e submeter o discurso próprio ao escrutínio do outro.

5 Designo como enunciado um segmento linguístico que possui um determinado grau de independência sintática e semântica em relação ao tecido discursivo. De certa forma, o conceito pode ser emparelhado ao que a gramática tradicional denomina como período (Ver: Ducrot (1987)). 
No primeiro enunciado, o autor afirma que a opinião das pessoas já foi levada em consideração, pois teria se importado muito com o que achavam dele. Com os dêiticos me e mim, refere-se a si mesmo e, com o marcador de pressuposição já, cria o pressuposto ${ }^{6}$ de que a recusa da opinião alheia não the pode ser imputada. Levar em consideração o ponto de vista do outro já fez parte da sua vida e teria sido um ingrediente relevante para a condução da vida prática cotidiana.

Porém, com o segundo, o autor afirma que dessa fase já largou, hipoteticamente, porque conduzir a vida a partir do que os outros pensam põe o indivíduo na condição de inibir desejos e vontades. Com o conectivo mas, ele afirma a desconsideração atual para com o que o outro pensa e, por meio do não, nega que tá bom para fulano ou sicrano seja o elemento definidor de suas atitudes e comportamentos.

No terceiro, o autor afirma que o que afeta a sua vida tem que tá bom para ele e não para fulano ou sicrano. Tomando-se como fio de avaliação, coloca-se como o foco do que lhe toca, já que o que o afeta deve estar bom para si (mim). O uso de apenas, por um lado, cria o pressuposto de que o que se refere à sua vida não tem que estar bom para os outros e, por outro, coloca-o numa redoma infensa à opinião alheia e sob o prisma da autossatisfação: sem consideração à visada alheia ou à renúncia ao que lhe agrada.

É a este funcionamento que me refiro como narcisismo discursivo, pois, à revelia do que o outro pensa, o indivíduo se recolhe para um mundo "particular", sem cogitar negociar um ponto de equilíbrio que possa contemplar a si e ao outro. Pondo-se como centro e fixando um lugar "pessoal" para as decisões, haverá motivos para dissensões que careceriam de alguma polêmica para iluminar a vida de uma maneira mais adequada. Eis o fio do discurso narcisista, pautado numa individualidade ética do eu para mim.

\section{PREPARANDO O TERRENO - MEME 2}

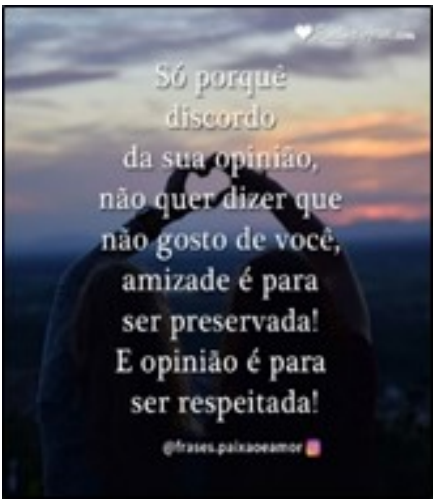

\section{Figura 2 - Meme 2}

Fonte: https://i.pinimg.com/originals/ae/dc/3f/aedc3f2588d5b4d9fbba1 aca66be339c.jpg

6 A pressuposição diz respeito ao fato de que determinados enunciados, além do posto/explícito, carregam um sentido pressuposto/anterior, como em “voltei”, que faz pressupor que "fui" (Ver Ducrot (1987)). 
Neste meme, o discurso é constituído por dois enunciados: um se refere deiticamente a um leitor genérico e o outro arremata a reflexão por meio de um slogan ou uma lição de moral. No primeiro caso, com os ingredientes linguísticos sua e você, o autor se volta para um interlocutor genérico que abarca qualquer um que se depare com o discurso em pauta. Além disso, com a repetição da negação canônica (não), evita a consequência inferencial de que discorda seja equivalente ou querer dizer que há antipatia ou animosidade (não gosto) para com o outro. A negação também impede que o uso do conectivo causal (porque) mostre um motivo para a discordância ser entendida como desafeto. Por fim, o uso do marcador de pressuposição (só), cujo escopo se refere a discordo, leva a inferir que, não havendo outra razão para discordância, a diferença não é motivo para criar aversão mais contundente. Em linhas gerais, portanto, a reflexão se constitui em torno da afirmação de que discordar não significa desgostar; ou seja: seria possível duas pessoas terem opiniões diferentes e gostarem uma da outra.

Mas, o efeito de sentido de liberalidade em relação aos pontos de vista, em que pese a aparência democrática, desanda sob a injunção do segundo enunciado. Formulada de maneira abrangente sobre a qual não há restrição, a amizade é colocada como atributo onipotente sobre o qual não pesa nenhum impeditivo e a opinião é um direito irrestrito. À luz do que fundamenta esta modalidade de funcionamento discursivo, a amizade se sobrepõe à divergência de opinião e não se tematiza qualquer forma de limitação ao que o próprio ponto de vista ou o do outro possam encampar. Essa liberalidade, porém, mesmo que o autor não pretenda este efeito, enquanto defende a permissividade do outro, autoriza (e exige) o direito de manter intocada a própria visada. Postular que a amizade está acima de tudo e que a opinião deve ser respeitada cria um caminho unilateral que exige ter a opinião que se queira sem submetê-la à polêmica e ao contradiscurso. Para além do efeito de flexibilidade frente ao que o outro pensa, o narcisismo discursivo, com o autoritarismo inflexível que o constitui, comanda o discurso e postula que cada um permaneça onde está, à revelia do contraditório, que pode ser produtivo e humanizador.

\section{PREPARANDO O TERRENO - MEME 3}

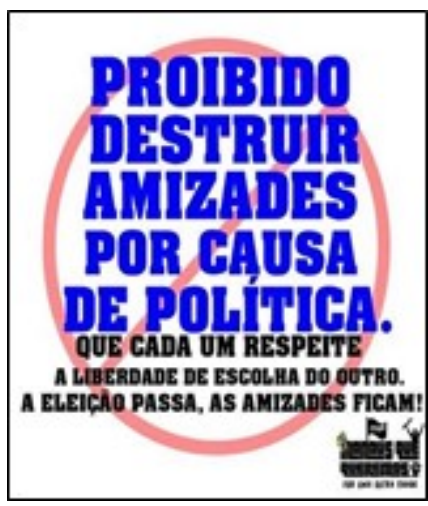

\section{Figura 3 - Meme 3}

Fonte: https://1.bp.blogspot.com/-

HWWq98YXoI/WsprFnzxSI/AAAAAAABAGM/p pZ3zRMICUrkL0dH17XQGaFEOIcxBESgCLcBGAs/s640/297 91863_1501953166584130_7810134222294745088_n.jpg 
No meme 3 existem três enunciados que constituem o discurso. No primeiro, amizade e politica são entrelaçadas, criando uma relação inferencial entre elas; no segundo, como slogan pedagógico, é emitida uma ordem que cada um deve cumprir; e, por fim, no terceiro, é estabelecida uma conclusão à luz do que foi afirmado. No primeiro enunciado, o autor postula que amizades não podem ser destruídas por causa de política; mais do que isso, sustenta que é proibido. Como todo provérbio, este não relativiza que amizade está em pauta, como não circunscreve a modalidade de atuação política. Amizade é tomada como um valor absoluto que se sobrepõe à opção política e política permite a leitura de que a escolha do outro (ou a própria) pode acontecer à revelia de opções que sejam perniciosas. Trocando em miúdos, as escolhas políticas podem ser prejudiciais, mas devem ser respeitadas para que a amizade não seja prejudicada.

Mantendo a perspectiva, o autor estabelece que cada um respeite a liberdade de escolha do outro, já que a amizade estaria acima das escolhas políticas. Se a tese sinaliza no sentido de que o outro pode optar por pontos de vista politicos de qualquer ordem, como reflexo sobre o autor, ele defende o direito de manter uma mirada. Com o pleito de a amizade não dever ser destruída pela opção política, o imperativo respeite abala a tese democrática, pois o respeito surge como um imperativo: trata-se de obrigar a ser flexível e plural, por meio do direito de continuar a ser de um modo imutável.

No terceiro enunciado, por meio do efeito de silogismo, o autor apresenta a razão para sustentar sua tese: a eleição passa, mas as amizades ficam; já que eleições são datadas e amizades, em tese, são duradouras, estas devem ser preservadas. Chama a atenção o postulado do respeito à escolha política, como se a opção não trouxesse, muitas vezes, decisões administrativas que prejudicam segmentos sociais que, mais do que os setores abastados, necessitam do poder público. Como nos outros dados, é possível detectar o narcisismo discursivo que postulo, dado que impor o respeito à opinião do outro é, por outro lado, exigir o respeito à opinião própria. Este modo de discurso se ampara no primado de que cada um pode escolher o que lhe aprouver, sem precisar colocar a opção sob o escrutínio dos outros, pressupondo que todos estão imbuídos da melhor boa vontade para com as necessidades sociais, o que, às vezes, não é constatável.

\section{PREPARANDO O TERRENO - MEME 4}

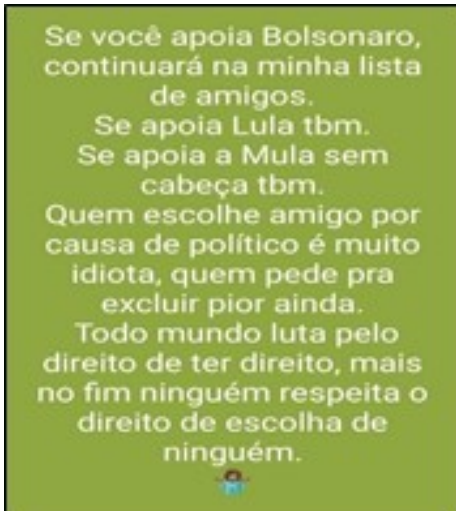

Figura 4 - Meme 4

Fonte: https://i.pinimg.com/originals/51/74/ee/5174eecea985aad0548f7f7ca87fbe7d.jpg 
Neste quarto caso, o material verbal é composto por cinco enunciados que se referem especificamente à sucessão presidencial de 2018. Nos primeiros três, o autor estabelece, por meio do conectivo condicional se, uma relação de sentido entre apoiar um candidato ou outro e continuar a fazer parte da sua lista de amigos no facebook. Para ele, o apoio a Bolsonaro, a Lula ou à Mula sem cabeça não fará com que exclua alguém do círculo de amizades. Com o uso do último sintagma destacado, acontece uma generalização que cria o efeito de que o apoio pode ser a qualquer um e nada irá interferir na mantença das amizades. O marcador de pressuposição também contribui para a criação do efeito de que os amigos se sobrepõem ao apoio a um candidato: qualquer que seja ele.

Para o autor, consoante o escopo enunciado, a escolha de um amigo por causa de político demonstra a idiotice de uma pessoa e aquele que exclui ou pede para excluir é ainda pior do que o idiota. Sendo pejorativo com quem usa parâmetro político para estabelecer laços de amizade, o autor busca demover aquele que se pauta nesse princípio e cria o pressuposto de que a opção política não pode definir os amigos que se terá; e pior: que aquele que o fizer, ou é idiota, ou é pior ainda. Os quatro primeiros enunciados criam uma relação de sentido entre apoiar quem quer que seja sem ruptura de laços de amizade e, se este pleito não for considerado, o comportamento ser insustentável.

No último enunciado, o autor produz uma conclusão geral, com o entrelaçamento de lutar pelo direito de ter direito e ninguém respeitar o direito de escolha. Na primeira parte, com o quantificador universal todo, ocorre a assunção de que cada um quer ter o direito de escolha acatado; na segunda, com o operador mais (mas), acontece a defesa de que ele direito não é respeitado por ninguém, quantificador também universal, equivalente a todos. Em outros termos, para o autor, a luta de todos por poder escolher e o respeito de ninguém a essa vontade revela que cada um aceita o que lhe aprouver, no limite, em atendimento à vontade "individual" de atribuição de sentido ao mundo.

Há ainda outra relação de sentido particular no enunciado final. Ao afirmar que ninguém respeita o direito de ninguém e defender que todos deveriam fazê-lo, no limite o autor postula que todos tenham o direito de escolher quem melhor lhe apeteça, tendo o comportamento que, de um ponto sociopolítico, não é o mais apropriado. Ou seja: de um lado, ele defende que todos tenham o direito de ter direito, o que significa que a vontade de cada um deve ser respeitada; de outro, ele afirma que ninguém respeita este direito, mas deveria fazê-lo. Se a luta pelo direito de escolha é direito de cada um e deve ser acatada por todos, a conclusão que se impõe é que cada um deve ser respeitado na opção política que fizer, mesmo que isto signifique apoiar a mula sem cabeça. Sustentando um discurso que parece democrático, flexível e plural, a tese de que cada um pense o que quiser, à revelia das consequências, no limite, legitima atitudes que não colocam o bem comum acima das vontades particulares, nem sempre as melhores. A assunção é que cada um fique ensimesmado no seu mundo particular, sem celeuma e sem polêmica: eis a presunção narcísica da leitura particular, com o autoritarismo que a acompanha. 


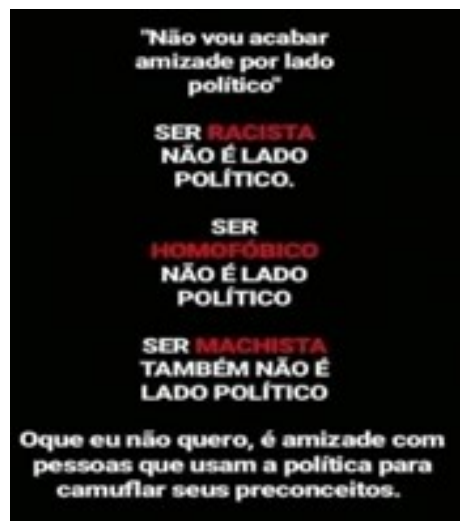

Figura 5 - Meme 5

Fonte: https://pbs.twimg.com/media/Dn1W6d8XcAA55se.jpg

O meme 5 é tecido por cinco enunciados e destoa dos demais, embora mantenha o prisma do narcisismo que postulo. Ele destoa, porque assume claramente que não querer amizade com quem faz determinadas opções e também porque rechaça certas escolhas, afirmando que elas não são lado político. Contudo, a recusa à polêmica e ao debate e a manutenção intacta de um ponto de vista permanecem como assunção/reivindicação, em que pese o caráter político "esclarecido" que sobredetermina o fio do discurso assumido.

No primeiro enunciado, por meio de aspas, o autor retoma, em discurso direto, um enunciado que povoou inúmeras memes postadas no facebook. Nelas, como no caso da última, a defesa era que lado político não deveria ser parâmetro para acabar com uma amizade, mesmo que a escolha incidisse sobre a mula sem cabeça. À primeira vista, o efeito da citação parece coadunar com o postulado nas outras postagens, com o autor assumindo que lado político não o levará a acabar amizade.

Porém, os enunciados seguintes estabelecem que racismo, homofobia e machismo são causa para terminar amizades, já que nenhuma destas atitudes é lado político, pois são sobredeterminadas por preconceito. Sustentando que ser racista, ser homofóbico ou ser machista não é lado político, estas seriam razões para a recusa de determinadas amizades. A reviravolta discursiva impõe o retorno ao enunciado inicial, com a obrigação de perceber que o autor assume que lado político não deve levar a acabar amizade, desde que seja um lado político e não uma atitude reprovável.

O efeito de sentido é confirmado pelo quinto enunciado, no qual o autor reafirma a manutenção de amizades com quem tem lado político, mas recusa ter amizade com quem usa a política para camuflar seus preconceitos. Assumindo que preconceitos não são lado político, mas motivo para não querer amizade, o autor não recusa outra escolha política, desde que seja uma opção política e não uma leitura ancorada sobre preconceitos.

Parece bem assentado que preconceito não é uma opção política e que o leitor é levado, neste caso, a concordar com o autor: pelo menos, os que se situam num horizonte avaliativo. Mas, em que pesem os motivos para o rechaço de determinadas amizades, é possível pleitear o recolhimento do autor para um mundo particular (mesmo que seja 
encorpado por outras pessoas), com a recusa de certos comportamentos e vontades. Tratase, antes, de o outro mudar o seu ponto de vista e, depois, de aceitar a visada do autor, para que a amizade seja possível: "você deve pensar como eu". Mesmo que as razões, então, sejam elogiáveis, ainda assim a recusa narcisista de outros discursos rejeita a polêmica e, quem sabe, a possibilidade de alteração da visada contrária.

7 PREPARANDO 0 TERRENO - MEME 6

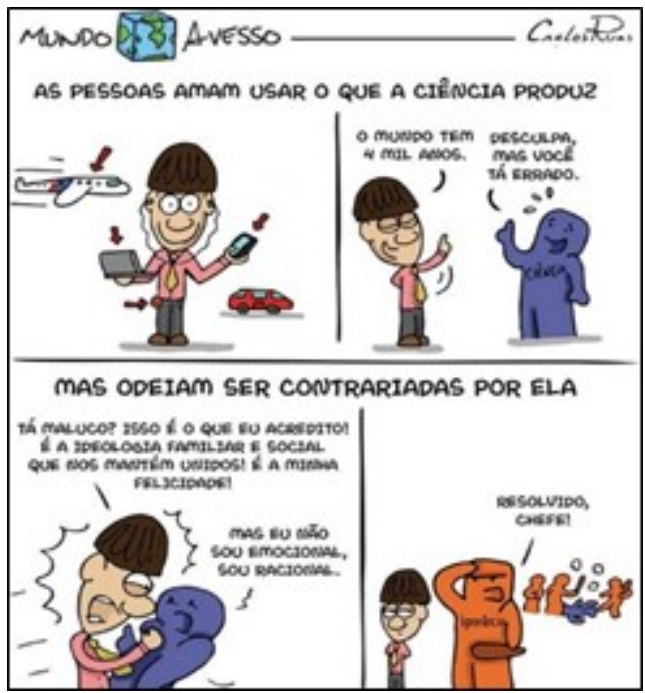

\section{Figura 6 - Meme 6}

Fonte: https://scontent.fcac1-1.fna.fbcdn.net/v/t1.09/65536832_2625825304095028_2688197984499269632_n.jpg?_nc_cat=105\&_nc_eui2=AeGcL7ZjTR_hqqPv_GK M3h4TuElsk̄CejuK16NM5D7wÜyj8XtcbSvxuy2vLbivGnMkTUkacMv19maR9bynYO8m1UBrvdtbzNYCdij36TtFafPg\&_nc_oc=AQmg11uePpPvqL5ufDdlnCAzm-IBiZ 6bZFRWOE76fDjS81fGSBHH2XwaxtwkAPmJ9g\& nc ht=scontent.fcac11.fna\&oh=3e5354beb84c5ec587209f7d2fb17aa5\&oe $=5 \mathrm{D} 82 \mathrm{D} 854$

Em relação a este meme, há seis enunciados que, em linhas gerais, tematizam a discrepância entre a razão lógico-científica e o campo da ideologia opinativa. O primeiro se assenta sobre uma afirmação constatativa, cujo efeito de sentido indicativo, dado o uso do presente do indicativo, define um limite de universalidade atemporal (as pessoas amam) e assume o que postula sob o modo da certeza positiva. $\mathrm{O}$ amor das pessoas pelo que a ciência produz é posto sob um efeito de evidência e, se houver discordância em relação à hipótesse, o primeiro quadro apresenta provas que corroboram a assunção.

No segundo quadro, acontece o primeiro embate entre o ponto de vista opinativo e a racionalidade científica. A personagem que aparece no primeiro quadro utilizando produtos tecnológicos desenvolvidos pela ciência afirma que o mundo tem 4 mil anos, sendo contradito pela pesquisa científica que atesta que ele existe há mais tempo. Ali, há uma opinião que carece de fundamentação demonstrativa; aqui, o contraditório a um ponto de vista insustentável. A personagem que se valia de bom gosto do que a ciência propiciou, agora, posta-se num terreno discursivo que vai contra a ciência. 
O quarto enunciado, mais matizado por vieses ideológicos, contradiz a tese de que o mundo tem mais de 4 mil anos e assume que a defesa está pautada num universo de crença em que é a ideologia familiar e social que mantém as pessoas unidas. O narcisismo que abordo é explicitamente assumido por ocasião do rechaço do ponto de vista científico, da defesa da crença particular e da superdeterminação da felicidade individual, à revelia de qualquer fonte mais embasada de polêmica. O narcisismo discursivo se mostra em eu acredito e minha felicidade, em que o indivíduo se sobrepõe ao contraditório, pautandose numa visada emocional e em contradição à racionalidade da ciência.

Como não há modo de convencer a ciência de que está equivocada, e no afã de salvaguardar uma posição débil, não sem hipocrisia e contradição, forças movidas pela emoção entram em cena e calam violentamente a ciência, recorrendo à repressão e ao silenciamento do que desagrada e impede a vontade de transmutar o mundo em espelho. De certa forma, a repressão movida pela ignorância não é mais do que a incapacidade de renunciar ao prazer e aceitar um ponto de vista mais acurado.

Este dado, sobretudo, é relevante porque mostra o pleito do narcisismo discursivo. Ele mostra como, em benefício de um ponto de vista, discursos são reprimidos em face da divergência; como diz a música, "Narciso acha feio o que não é espelho". Além disso, em que pese a defesa do autor estar postada ao lado da ciência, ele não deixa de se recolher a um ponto de vista infenso (e com razão, talvez) ao que vai contra suas hipóteses. $\mathrm{O}$ narcisismo também assombra este campo, na medida em que se fecha para a polêmica e para a abertura a outras leituras. No limite, o autor assume o fio de sentido que postula que as pessoas não deveriam odiar ser contrariadas pela ciência.

\section{PREPARANDO 0 TERRENO - MEME 7}

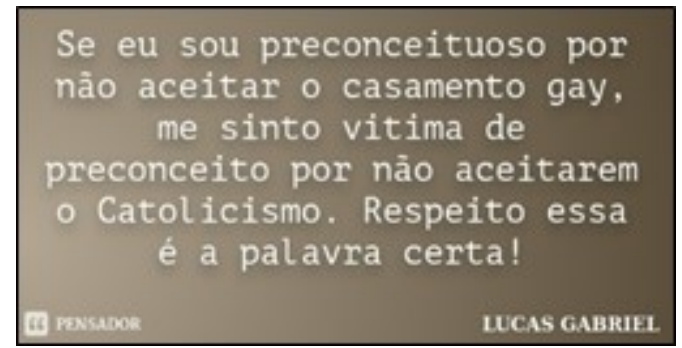

\section{Figura 7 - Meme 7}

Fonte: cdn.pensador.com/img/frase/lu/ca/lucas_gabriel_se_eu_sou_preconceituoso_por_nao_aceitar_lyne5pr.jpg

Neste meme, pode-se perceber que há um bailado entre a homossexualidade e o catolicismo, duas temáticas complexas, dado que a pertença a um segmento impõe a ruptura com o outro, em que pese um se referir à sexualidade e o outro à crença religiosa. Tudo se passa como se a fé católica barrasse o homossexualismo, com uma armada de preconceitos, ou a orientação sexual proibisse a vivência de um preceito religioso. Pelo discurso é tecida, dessa maneira, uma relação silogística entre a homossexualidade e o catolicismo, com um rechaçando o outro, pois ser homossexual levaria a se postar contra o catolisicmo e ser católico deveria levar a rechaçar o homossexualidade. 
No caso deste meme, o autor, que parece alocado sob a rubrica religiosa, é pego num bailado, pois, por não aceitar o casamento gay, sente-se vítima de preconceito, já que um segmento social não aceita os dogmas do catolicismo, ingrediente que prepondera no discurso, em face da escrita com maiúscula (o uso desta grafia não deixa de estabelecer uma comparação entre a homossexualidade e o catolicismo, em benefício deste). Posto num beco sem saída, considerando a sua crença religiosa, o autor se vê na obrigação de rechaçar o casamento gay e, por isso, sofre preconceito. Caso aceite a homossexualidade, é de dentro da sua orientação religiosa que a reprovação acontecerá. Pego no confronto entre dois discursos, não há saída, pois um deles será fonte de preconceitos e atribuições de sentido, no mais das vezes infundadas e humanamente discriminatórias.

Conforme o autor, a saída do dilema é o respeito, já que esta é a palavra certa (grifo meu) para evitar dissenções. Ou seja: a resolução da celeuma viria da aceitação. Embora respeito possa significar superação de preconceitos e discriminação, a defesa não incide sobre o aceite do discurso do outro. Trata-se, no limite, de a homossexualidade ser rejeitada pelo catolicismo e o catolicismo ser criticado pelos homossexuais. Nenhuma perspectiva de inserção aparece: que cada um se mantenha onde está. Percebe-se, assim, a toada do narcisismo discursivo subsumido pelo respeito à verdade do outro.

9 PREPARANDO O TERRENO - MEME 8

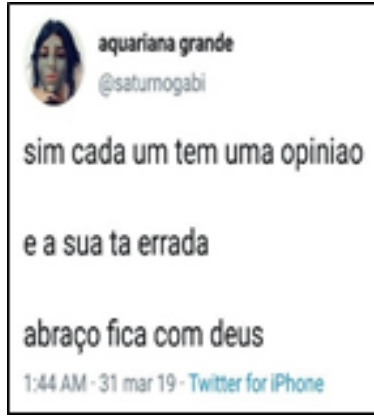

Figura 8 - Meme 8

Fonte: https://pbs.twimg.com/media/D3GwlQuXcAAp2XJ.jpg

Neste meme, quase evidente em relação à hipótese defendida, há três enunciados. No primeiro, o autor, com um efeito de liberalidade, por meio do advérbio de afirmação sim, reconhece a existência de uma pluralidade de opiniões, pois cada um tem a sua. $\mathrm{Na}$ pressa, alguém poderia concluir que o autor respeita a diversidade. Mas, de forma taxativa, ele afirma que o outro (sua) está errado, valendo-se do conectivo e, que, no discurso, tem valor adversativo. Este enunciado obriga a rever o efeito do primeiro, impondo perceber que a opinião do outro é descartada, sem celeuma ou polêmica. A aparência de abertura para a multivalência, dessa maneira, fica subsumida pelo tom autoritário e unilateral.

Por fim, mesmo o tom afetuoso que sobredetermina o enunciado final deve ser posto sob um diapasão de ironia sarcástica; sobre ele, pesa uma entonação de menosprezo para com o que o outro pensa e a despedida é apenas a determinação do silenciamento e da desconsideração para com o outro. Neste caso, o narcisismo discursivo é palpável. 


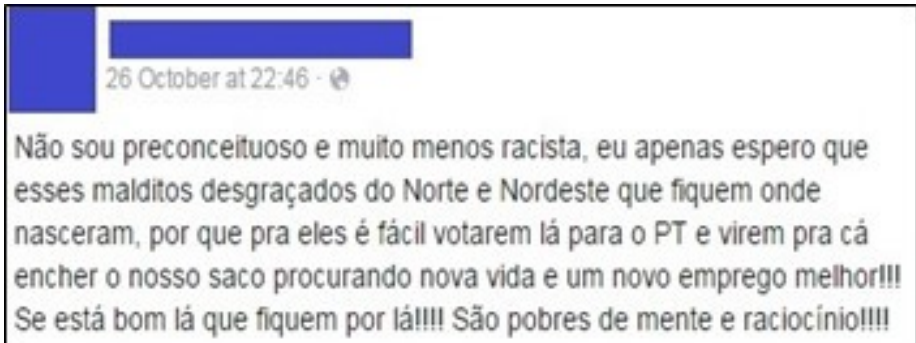

Figura 9 - Meme 9

Fonte: https://66.media.tumblr.com/b45248cdc16aef78ee73884e27f7f233/tumblr_neowbjAD0f1qirrtjo1_540.jpg

No último meme, o narcisismo discursivo aparece de modo explícito, sendo determinado por uma perspectiva de autocentramento desrespeitoso e discriminatório. Limito-me a chamar a atenção para a negação (não) que deve ser lida como denegação (como afirmação), em face do que é tecido à frente e que mostra o caráter (ou a falta dele) preconceituoso do autor. Sob o fio da meada dos outros dados de que me vali, entendo que o narcisismo aqui seja grandiloquente em demasia, para exigir que outros comentários sejam tecidos ou que alguma "consideração" de maior relevância seja apresentada.

\section{TEORIZANDO O NARCISISMO DISCURSIVO}

Nesta seção, trago algum amparo teórico para a defesa da hipótese que defendo. Valho-me, sobremaneira, do texto "Animismo, magia e onipotência de pensamentos", da obra Totem e Tabu, de Freud (2005). Nela, com base em autores que voltaram a atenção para os homens primitivos e se valendo de manifestações dessas comunidades, o autor postula que o homem desenvolveu, na história, três grandes sistemas de pensamento ou três grandes formas de representação do universo: a animista (ou mitológica), a religiosa e a científica. $\mathrm{O}$ animismo se refere ao entendimento de que o universo é habitado por almas/espíritos e os objetos inanimados são dotados de vida anímica. Por isso, o homem teria buscado dobrar o mundo a sua vontade e desenvolvido uma teoria geral da natureza. É sob este escopo de percepção que se falava em espírito da água, do fogo, da terra, do ar, do lobo, do urso, da águia, da raposa (esse processo de metaforização não deixou de existir, sendo utilizado assiduamente na vida moderna) e se atribuía a cada um o espírito de um destes seres como protetor. Por meio do animismo, o homem teria chegado a uma chave explicativa global e feito as leis do real se submeterem, em tese, à vida psicológica, uma vez que teria imposto "as leis que regem a vida mental às coisas reais" (p. 98). O primado deste sistema de pensamento, para Freud, reside na supervalorização dos atos psíquicos ou no que o autor denomina "onipotência de pensamentos" (p. 92), que faz, em última instância, o mundo ser aquilo em que se acredita.

$\mathrm{Na}$ tentativa de dominar os espíritos, o homem teria criado um leque de rituais de magia e de feitiçaria, cuja meta seria fazer com que eles o servissem, atendendo a seus desejos e satisfazendo suas necessidades. Como esta busca de controle não podia deixar 
de estar fadada ao fracasso, já que o sol e a chuva, por exemplo, não se submetiam, o homem, vagarosamente, reconhecendo a impotência, teria avançado para o sistema religioso, erigindo os espíritos insubordinados à categoria de deuses, e o que antes era ordem teria se transformado em prece. Mesmo que o universo continuasse povoado por espíritos, os mais proeminentes para a vida prática se tornaram divindades celebradas e adoradas, para que melhor pudessem colaborar com os desígnios humanos.

Porém, apesar das orações, celebrações e oferendas, os deuses não se submeteram, levando à busca de controle do mundo por outros meios, chegando ao sistema científico, calcado na busca da descoberta da racionalidade das coisas. Superando as fases mítica e fase religiosa, o homem buscou outro modo de impor a sua vontade ao mundo, por meio da descoberta de suas leis, submetendo-se, quando não há maneira de fazê-lo atender aos seus desejos. Se, na primeira fase, o homem era o centro do mundo, na segunda, ele estava descentrado e, na terceira, enfim, seria determinado pelo que não controla.

Para Freud, sendo aceita esta teorização sobre a maneira de o homem se postar face ao universo, a onipotência de pensamentos varia de forma nos diferentes momentos. No primeiro, os homens atribuem a onipotência a si mesmos; no segundo, aos deuses, buscando colocá-los a favor; e, no terceiro, reconhecem a impotência, submetendo-se à morte e a outras leis naturais, sem deixarem de buscar o controle das determinações que lhes escapam. Sem postular que uma etapa suceda ou elimine a outra, Freud atenta para o fato de que cada momento mantém a presunção de potência, se não porque o homem "sabe tudo" ou porque invoca os deuses, mas porque busca dominar a natureza.

Dada esta breve sumarização sobre os sistemas de pensamento, atento para o que interessa ao caso: a supervalorização da vida psíquica ou a onipotência de pensamentos. Mesmo que o homem tenha que reconhecer a debilidade do seu poder sobre o mundo, não deixa de acreditar que pode controlar o que o cerca. A espiritualização como forma de produzir um conhecimento global, a criação de deuses para invocá-los ou a pesquisa da realidade para dominá-la mostram que o homem hiperboliza a capacidade psíquica, sendo determinado pelo desejo e pelo princípio do prazer, que não pode ser reprimido senão sob pena de desenvolvimento de distúrbios psíquicos. De acordo com o autor, "os desejos são acompanhados de um impulso motor, a vontade, que está destinado a alterar toda a face da terra para satisfazer seus desejos" (p. 90).

O ponto de inflexão que reitero se refere ao fato de que, dada a necessidade de escrutinar o mundo à revelia e construí-lo à imagem e semelhança, o homem se pauta no animismo primitivo, recusando-se, às vezes violentamente, a reprimir o desejo e a vontade e se negando a aceitar teses religiosas ou científicas que desdigam uma apreensão mais conveniente. Como os memes observados mostram, às vezes a liberalidade e a abertura para a diversidade são só um efeito que aponta para um funcionamento discursivo que se ancora no preceito de o mundo ser o que se quer que seja, contra qualquer evidência. Se, para Freud (p. 104), "a repressão aos instintos é a medida do nível de civilização que foi alcançado", memes como os analisados revelam a falta de controle, a sobredeterminação do desejo e o autocentramento umbilical que se recusa à polêmica. Trata-se de admitir que o outro se mantenha onde está para evitar se mover para outra leitura.

Pautado na defesa da existência dessas três formas de representação do universo, por meio de deslocamento analógico ou de metaforização, Freud as emparelha às fases 
distintas do amadurecimento do indivíduo. Para ele (p. 96), "se podemos considerar a existência da onipotência de pensamentos entre os homens primitivos como uma prova em favor do narcisismo, somos incentivados a fazer uma comparação entre as fases do desenvolvimento da visão humana do universo e as fases do desenvolvimento libidinal do indivíduo". Desse modo, Freud emparelha a fase animista à etapa narcisista, em que o indivíduo tem a si como foco de satisfação, obtendo prazer no próprio corpo, o que ele denomina como "autoerotismo" (p. 95); a fase religiosa, à etapa da escolha do objeto, "cuja característica é a ligação da criança com os pais" (p. 96); e a fase científica à etapa em que o indivíduo "ajusta-se à realidade e volta-se para o mundo externo em busca do objeto de seus desejos" (p. 97). Sob esta compreensão da evolução humana, em que pese ela poder, em tempos modernos, ser anímico-narcisista, e da evolução das tendências libidinais, Freud encontra o suporte necessário para construir o primado do narcisismo.

Para ele, seriam reconhecidas até então duas fases do desenvolvimento libidinal. A do autoerotismo ocorreria enquanto os componentes instintivos atuam em separado, agindo à revelia uns dos outros, embora sob a determinação da sexualidade. A segunda, da escolha do objeto, viria a seguir e, então, o indivíduo não mais projetaria o prazer sobre si mesmo ou sobre os pais, mas buscaria se satisfazer pelo encontro de um objeto externo. Freud afirma que estudos mostraram que "é conveniente e verdadeiramente indispensável inserir uma terceira fase entre aquelas duas" (p. 95). Nesta, "os instintos sexuais até então isolados já se reuniram num todo único e encontraram também um objeto. Este objeto, porém, não é um objeto externo, estranho ao sujeito, mas se trata do próprio ego" (p. 95). Aqui, "o sujeito comporta-se como se estivesse amoroso de si próprio; seus instintos egoístas e seus desejos libidinais ainda não são separáveis pela nossa análise” (p. 95).

Alcanço o ponto a que queria chegar: apesar de o terreno não ser intrinsecamente sexual dado que ele aparece como a sublimação que desvia a energia para outra direção (talvez haja, aqui, um prazer - oral - derivado do discurso), é possível postular a existência de uma vontade narcisista ${ }^{7}$ determinante do funcionamento discursivo. Admito que estou importando o conceito de narcisismo do campo psicanalítico para o discursivo, defendendo que, assim como lá, aqui, o indivíduo está (ego)centrado e enamorado do que pensa à revelia do mundo. Se o mundo não confirma o que ele pensa, pior para o mundo, pois, para ele, "as coisas se tornaram menos importante do que as ideias das coisas" (p. 91). Esta conduta "é o resultado da virtude suprema que atribui aos seus desejos, da vontade que está associada a estes desejos e dos métodos pelos quais os desejos operam" (p. 91). Em que pesem os ditames sociais que atuam sobre o funcionamento discursivo, o narcisismo cega para as evidências lógico-racionais que lhe apresentem, revelando "uma nova arrumação do material psíquico que é feita com um novo objetivo em vista” (p. 102), mesmo que "a redisposição tenha que ser radical (para que) o resultado pareça inteligível do ponto de vista do sistema" que o determina (p. 102). Em outras palavras, ele é "afetado apenas pelo que é pensado com intensidade e imaginado com emoção, ao passo que a concordância com a realidade externa não tem importância” (p. 93).

7 Como, em linhas gerais, este trabalho está alocado sob a rubrica da Análise de Discurso, a escola de linha francesa também garantiria um mirante suficiente para a demonstração da hipótese que apresento. No entanto, a opção por buscar em Freud a sustentação teórica maior se deve ao fato de que a teorização sobre o narcisismo (que aqui observo no discurso) foi definitivamente assentada por este pensador. 
A modalidade de funcionamento do discurso que busco ressaltar diz respeito ao fato de que, à revelia de evidência comprobatória em contrário, o narcisista se pauta no que acredita ser a verdade e, em face da renitência do outro em aceitar um ponto de vista, às vezes, infundado, ele se recolhe num universo anímico que refrata qualquer tentativa de dissuasão e se refugia, de modo "plural e flexível", no "respeito" ao que o outro pensa, como fuga da necessidade de crivar a sua compreensão de mundo e escrutinar a objeção com que se depara. Se este for o caso, será necessário discutir a tese cara à Análise do Discurso, da interpelação ideológica, com que concordo, mas me parece não recobrir o que acontece nesta forma de funcionamento, já que a coincidência com o outro (cúmplice e conivente) só aparece como reforço de um mundo bastante particular.

Postulo que, para além da aparência de aceitação de que o (o)Outro permaneça onde está, há uma vontade (não só ideológica) que se recusa a considerar o que ele tem a dizer (de certo modo, uma recusa "religiosa") e a perscrutar o que pensa tomando como parâmetro as evidências cotidianas que podem esburacar o comportamento (neste caso, a recusa se dá em relação à cientificidade e se sustenta na defesa da permanência renitente no espelho que só mostra o próprio rosto). O que este comportamento discursivo aponta é a assunção de um mundo particular que só se satisfaz quando encontra o acordo.

Em face da "parcialidade" da reflexão feita, chamo a atenção para o fato de que não afirmo que aquele que toma partido por uma convicção seja sempre parcial e infenso à polêmica, por ser atravessado por uma mirada narcísica. Às vezes, a recusa de mudar de posicionamento está calcada na cientificidade lógico-racional, e o respeito à opinião do outro só tem o intuito de não se submeter a uma celeuma infrutífera. Não há por que discutir se a terra é redonda: ela é. Estou situando o narcisismo discursivo naqueles casos em que, contra qualquer evidência objetiva, "sistemas" são rearranjados com explicações inseguras, para manter um prisma que permite evitar o contradiscurso.

O narcisismo discursivo, com base nos dados, refere-se ao fato de que o indivíduo, fechado num mundo particular, recusa-se a tematizar o horizonte avaliativo, ou porque é incapaz de renunciar ao princípio do prazer, recluindo-se a um universo hedonista pessoal, ou porque está convicto de que a sua verdade é "a" verdade e que o outro só pode estar enganado, rejeitando a polêmica e a mudança de ponto de vista em benefício de uma mirada mais bem assentada, porque ela é mais evidente ou porque, humanamente, é mais adequada. Esta atitude diz respeito ao caso em que o indivíduo rejeita a revisão e, para manter um efeito de flexibilidade, permite que o outro acredite no que quiser, por mais que o seu posicionamento ou o do outro possam ser infundados. Para que o seu narcisismo continue intocado, ele apoia o narcisismo do outro, construindo um narcisismo radical que só faz recrudescer aquilo que, às vezes, carece de alteração imediata.

Os dados trazidos mostram que, às vezes, para não alterar seu ponto de vista, mesmo que à luz de evidências objetivas, o indivíduo simula um espírito democrático e de respeito para evitar o debate, a celeuma e a polêmica. Ao ter este comportamento e sem perceber as determinações que pesam sobre o mirante em que se postou, há, por detrás da "liberalidade", a persistência em torno de um universo próprio, com a pressuposição, no limite, de que o outro está equivocado. Em outros termos: a aparência de democracia aberta à diversidade e à pluralidade, no fundo, esconde um autoritarismo radical e refratário à revisão. A recusa ao escrutínio do seu mundo, com a mudança de crença que 
ela poderia impor, mesmo que sob aparência simpática e amigável, não é menos do que a convicção profunda de que o outro está errado e que é melhor não discutir com quem não consegue ver a verdade: eis a sofomania. A verdade pessoal é "a" verdade e, se o outro não a aceita, pior para ele, que não consegue perceber o mundo irracional em que se encontra.

\section{CONSIDERAÇÕES FINAIS}

Penso que os dados trazidos para este trabalho - e poderia ter trazido outros que tenho recolhido nos passeios pelo facebook (o leitor, se resolver percorrer este caminho, não terá dificuldade de encontrar outros tantos) - dão conta adequadamente de demonstrar o fio de funcionamento do discurso que se pauta no narcisismo individual voltado para o autocentramento e para a autossatisfação. Às vezes, ele se simula flexível e plural; às vezes, ele se faz francamente violento; e, às vezes, ele se constrói sob uma perspectiva autoritária de surdez cabal e apriorística em relação ao discurso do outro. Neste sentido e para essa modalidade de discurso, o ponto de vista anímico (que povoa os espíritos dos outros com o mal/mau/erro/ingenuidade/ignorância/alienação), contrariamente ao ponto de vista religioso (a boa representação) e, sobretudo, ao sistema científico, prepondera e não se abre para apreensões que são mais bem embasadas em face do mundo objetivo e daquilo que interessa para o bem comum.

Devo fazer um esforço a mais para circunscrever o que estou designando como narcisismo discursivo. Poderiam me contradizer, afirmando que todo discurso é de cunho narcisista, na medida em que só reconhece a "sua" própria verdade, em geral, sustentada por vieses políticos e ideológicos. Se fosse assim, todo discurso seria narcisista e, no limite, nenhum seria. No funcionamento do discurso que trouxe para a reflexão, porém, o narcisismo é levado às raias da falta de vontade, porque se recusa peremptoriamente à discussão e à possibilidade de negociação dos sentidos, admitindo que possa rever os seus pleitos e alterar os postulados do outro. Parece-me óbvio (mas o óbvio nem sempre é tão óbvio) que o discurso científico não tem porque ser revisado e aberto à polêmica, até que se prove que há uma solução mais simples e elegante ou que ele está equivocado. Mas entendo que mesmo ele tem a obrigação de se abrir para o ensinamento pedagógico de respeito ao outro. O narcisismo discursivo de que trato diz respeito à discursividade que, ensimesmada num mundo particular refratário ao divergente, em geral baseado em dogmas de fé ou ideológicos (ou em ambos), só se contenta quando ouve aquilo que quer ouvir e se regozija na assunção de um sentido apriorístico.

Considero, ainda, um contra-argumento à existência do narcisismo discursivo, contraditório que já me foi apresentado; ele se refere à defesa de que o narcisismo de que trato, antes de tudo, é atitudinal ou comportamental e não propriamente discursivo. Só posso responder a essa mirada oposta afirmando que não tenho acesso à vida prática de quem produziu os memes analisados e tenho que me satisfazer com a materialidade discursiva que possuo à disposição e que me dá o suporte necessário para postular o princípio do funcionamento discursivo que teorizo. 
E, para arrematar: à luz dos dados trazidos para este trabalho (e de inúmeros outros que circulam nas redes sociais e em outros suportes - a que o leitor poderá aceder), é possível postular que, contrariamente à suposição de que o homem galgaria um caminho que o levaria da mitologia à religião e à ciência, com uma sucedendo a outra em termos de aprimoramento da racionalidade, em última instância, à revelia de qualquer base maior de sustentação objetiva, discursos como os analisados mostram que, às vezes, as pessoas preferem povoar o mundo com espíritos que arbitrariamente impõem sobre os demais, refratando a possibilidade de revisão a que poderiam conduzir ou ser conduzidas à luz de evidências que contradizem o que pensam. Em outras palavras, o fio de funcionamento das materialidades discursivas observadas mostra que a onipotência de pensamentos determina certos discursos, já que partem do princípio de que as coisas devem se adequar à crença e de que, se elas não se dobram à vontade, devem ser rechaçadas, às vezes, sob a defesa débil de que cada um deve respeitar o direito do outro, para melhor satisfazer a vontade de viver o narcisismo do "eu para mim".

\section{REFERÊNCIAS}

DUCROT, O. O dizer e o dito. Rev. trad. Eduardo Guimarães. Campinas: Pontes, 1987.

FREUD, S. Animismo, magia e onipotência de pensamentos. In. FREUD, S. Totem e tabu. Trad. Órizon Carneiro Muniz. Rio de Janeiro: Imago, 2005.

FREUD, S. O mal-estar da civilização. Trad. José Octávio de Aguiar Abreu. Rio de Janeiro: Imago, 1997. MAINGUENEAU, D. Gênese dos discursos. Trad. Sírio Possenti. Curitiba: Criar Edições, 2005.

PÊCHEUX, M. Análise Automática do Discurso (AAD-69). In: GADET, F.; HAK, T. Por uma análise automática do discurso: uma introdução à obra de Michel Pêcheux. Trad. Bethânia S. Mariani et al. 2. ed. Campinas, SP: Editora da UNICAMP, 1993.

PÊCHEUX, M. Semântica e discurso: uma crítica à afirmação do óbvio. Trad. Eni Puccinelli Orlandi et al. 2. ed. Campinas, SP: Editora da Unicamp, 1995.

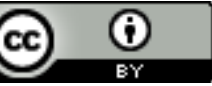

Este texto está licenciado com uma Licença Creative Commons Atribuição 4.0 Internacional. 